\title{
Cytotoxic Activity of Stem of Pycnarrhena cauliflora through Apoptosis Induction on Human Breast Cancer Cell Line T47D
}

\author{
Masriani $^{1^{*}}$, Rudiyansyah ${ }^{2}$, Rini Muharini ${ }^{1}$, Eny Enawaty $^{1}$ \\ ${ }^{1}$ Chemistry Education Department, Faculty of Teaching and Education, Tanjungpura University, West Kalimantan, Indonesia \\ ${ }^{2}$ Chemistry Department, Faculty of Mathematics and Natural Sciences, Tanjungpura University, West Kalimantan, Indonesia
}

\section{ARTICLE HISTORY \\ Received: Juli 2019 \\ Revised: August 2019 \\ Accepted: November 2019}

*Corresponding author

Email:masriani@fkip.untan.ac.id

\begin{abstract}
Cytotoxic activities of extracts of Pycnarrhena cauliflora leaves, stems and roots on some human cancer cells have been known. However, the cytotoxicity of stem of Pycnarrhena cauliflora on human breast cancer cell line T47D through an apoptosis induction has not been proven yet. This study was an effort in understanding the cytotoxic activity of stem of Pycnarrhena cauliflora through apoptosis induction. The crude ethanol extract was partitioned between $n$-hexane and dichloromethane at $\mathrm{pH} \mathrm{3,7}$ and 9, which was subsequently tested for their cytotoxic activity against human breast cancer cell line T47D by using 3-(4,5-dimethylthiazol-2-yl)2,5-diphenyltetrazolium bromide (MTT). Flow cytometric analysis with Annexin V-FLUOS/ propidium iodide (PI) double staining was used for apoptosis analysis. The dichloromethane fraction at $\mathrm{pH} 7$ was considered the most potent with an $\mathrm{IC}_{50}$ value of $59.30 \mu \mathrm{g} / \mathrm{mL}$ and induced apoptosis on the T47D cell line. The result indicated the potential of dichloromethane fraction of the stem of P.cauliflora as a source of bioactive compounds and provided a basis of further studies to isolate a new anticancer compound.
\end{abstract}

Keywords: Pycnarrhena cauliflora; cytotoxicity; apoptosis; T47D

\section{INTRODUCTION}

Cancer is one of the major causes of death worldwide. According to GLOBOCAN, the number of new cases and death caused by cancer in 2018 was 8.1 million and 9.6 million (Bray et al., 2018). One in 8 men and 11 women of deaths in the world is caused by cancer. Breast cancer is the second most common malignancies $(11.6 \%)$ and the second cause of cancer deaths worldwide $(6.6 \%$ of total cases) (Siegel et al.,2018).

Various strategies for cancer treatment have been carried out, but the morbidity and mortality rates are still high. Cancer treatment strategies can be carried out either single or in combination through surgery, chemotherapy and radiation methods (Taraphdar et al., 2001; Vijayalaxmi et al., 2002; Rogers, 2003). Chemotherapy is the most important method in treating cancer, especially for metastatic cancers. The main problem in treating cancer with chemotherapy is the emergence of serious side effects (Sausville and Longo, 2005) and multidrug resistance (Tsuruo, 2003; Li et al., 2005). This led to the discovery of new anticancer drugs.

Natural resources have played an important role in the field of cancer drug discovery and development. During 1981 to 2006, natural resources represented about $47.1 \%$ of 155 of drugs in clinical application (Newman and Cragg, 2007). World Health Organization
(WHO) predicted about $80 \%$ of the developing world's population relies on traditional herbal medicines for their primary care (Alves and Rosa, 2005).

Pycnarrhena cauliflora (Menispermaceae) is one of indigenous plants of West Kalimantan which is locally well known as sengkubak or sanksang. The Dayak and Malay ethnic groups used the leaves of the plant as a natural taste substance (Afrianti, 2007). The ethanolic extract from leaves of $P$. cauliflora showed a weak antioxidant activity by scavenging of DPPH free radical with $\mathrm{IC}_{50}$ value of $565 \mu \mathrm{g} / \mathrm{mL}$ (Masriani et al., 2011). In addition, the ethanolic extract from leaves, stems and roots of $P$. cauliflora exhibited cytotoxic activity on human cervical cancer HeLa cell line. The roots of ethanolic extract induced apoptosis and caused cell cycle arrest at the G0/G1 phase (Masriani et al., 2013). The crude alkaloid of $P$. cauliflora root showed potent cytotoxic activity and high selectivity on T47D cancer cells. The cytotoxic effect was triggered by inducing of apoptosis and arresting of cell cycle at G2/M phase (Masriani et al., 2014).

Anticancer activity against breast cancer T47D cell lines of P. cauliflora stem has not been well studied. Accordingly, we evaluated cytotoxicity of ethanol extract of $P$. cauliflora stem in the breast cancer T47D cell lines, furthermore we confirmed it activities in the apoptosis induction process. It was expected that the 
results of this study can provide a basis of further studies in a new anticancer drug development.

\section{MATERIAL AND METHODS}

\begin{abstract}
Material
The main material used in this research was P.cauliflora stem. Other materials used were ethanol $95 \%$ and $\mathrm{CH}_{2} \mathrm{Cl}_{2}, n$-hexane; distilled water; $\mathrm{HCl}$ and $\mathrm{NaOH}$ (pro analysis grades, Merck, Germany); medium RPMI (Gibco, USA); MTT [3-(4,5-dimethylthiazol-2-yl)2,5-diphenyl- tetrazolium bromide] (Sigma, USA); Fetal Bovine Serum (FBS) (Caisson, USA); phosphate buffer (Gibco, USA); trypsin-EDTA $0.25 \%$ (Gibco, USA); Annexin V-FLUOS double staining saline (PBS); penicillin-streptomycin; fungizone/amphotericin (Gibco, USA) and SDS (Merck, USA).
\end{abstract}

\section{Equipment}

The main tools used were ELISA reader (Bio-Rad, Japan), Haemocytometer (Neubauer, Germany), $\mathrm{CO}_{2}$ incubator (Heraeus ${ }^{\circledR}$, Germany), and inverted microscope (Olympus, Japan).

\section{Methods}

\section{Extraction of crude extract and solvent partitioning}

The air-dried powder of P.cauliflora $(4.6 \mathrm{Kg})$ stem was macerated in ethanol (24 L) for $3 \times 5$ days. The resulted residue ( $245 \mathrm{~g}, \mathrm{SE})$ was dissolved in distilled water and partitioned with successive solvent of $n$-hexane and dichloromethane at $\mathrm{pH} 3,7$ and 10 to obtain $n$-hexane fraction $(8 \mathrm{~g}, \mathrm{SH})$ and dichloromethane fractions at $\mathrm{pH}$ 3 (10 g, SD3), pH 7 (15 g, SD7) and pH 10 (5 g, SD10). The extract and fractions were dissolved in dimethyl sulphoxide (DMSO) to give a stock solution of $100 \mathrm{mg}$ / $\mathrm{mL}$ and stored $\left(-20^{\circ} \mathrm{C}\right)$ until used.

\section{Cell line and culture}

Human breast cancer cell line T47D was used for in vitro cytotoxicity assays. The cell line used in this study was obtained from Parasitology Laboratory, Faculty of Medicine, Gadjah Mada University, Yogyakarta, Indonesia. RPMI-1640 medium, supplemented with 10\% FBS, 2\% penicillin/streptomycin and 5\% amphotericin was used as the culture medium for T47D cell. The cell line was grown and maintained in a humidified incubator at $37^{\circ} \mathrm{C}$ with $5 \% \mathrm{CO}_{2}$ atmosphere.

\section{Cell cytotoxicity assay (MTT assay)}

The cytotoxic effect of $n$-hexane fraction (SH) and dichloromethane fractions at $\mathrm{pH} 3$ (SD3), $\mathrm{pH} 7$ (SD7) and $\mathrm{pH} 10$ (SD10) on T47D cell line was determined by MTT colorimetric assay (Mosmann, 1983). Briefly, cells $\left(1 \times 10^{4}\right.$ cells/well $)$ were seeded into 96 -well flat bottom culture plates and allowed for overnight to adhere in incubator at $37^{\circ} \mathrm{C}$ with $5 \% \mathrm{CO}_{2}$ humidified atmosphere. Afterwards, cells were treated with culture medium (cell control) and various concentrations of fractions (final concentration from 31.25 to $500.00 \mu \mathrm{g} / \mathrm{mL}$ ) and incubated for $24 \mathrm{~h}$. Three replicate wells were used per concentration. At each end time point, the media was discarded and cells were washed with PBS once. Each well was added with $110 \mu \mathrm{L}$ of mixture of MTT solution $(5 \mathrm{mg} / \mathrm{mL})$ and complete medium (1:9). The cells were again incubated for 3-4 h. At the end of incubation, the reaction was stopped by $100 \mu \mathrm{L}$ sodium dodecyl sulphate in $\mathrm{HCl} 0.1 \mathrm{~N}$ to each well and permitted for overnight in dark at room temperature for complete dissolution of formazan crystals. The absorbance of each well was read at $595 \mathrm{~nm}$ using an enzyme-linked immunosorbent assay (ELISA) reader. The results were expressed as the percentage of viability cells in comparison to the control cells, using the following formula:

Viable cells percentage $=\frac{\text { absorbance of trated cells }- \text { absorbance media }}{\text { absorbance of control cells }- \text { absorbance media }} \times 100 \%$

The concentration required to inhibit $50 \%$ the cancer cells growth population or $\mathrm{IC}_{50}$ was calculated by using regression analysis of viable cells percentage graph against concentration.

\section{Flow cytometric analysis of cell apoptosis}

The T47D cells $\left(5 \times 10^{5}\right.$ cells/well $)$ were seeded onto 6 -well plates (Iwaki, Japan) in a final volume $2 \mathrm{~mL} /$ well. The cells were incubated with $2 \mathrm{~mL} /$ well of the three different concentrations of SD7 and incubated at $37{ }^{\circ} \mathrm{C}$ with $5 \% \mathrm{CO}_{2}$ for $24 \mathrm{~h}$. The cells were treated with SD7 with three different concentrations (60.0, 120.0 and 180.0 $\mu \mathrm{g} / \mathrm{mL}$ ). After $24 \mathrm{~h}$, the cells were harvested, collected and re-suspended in $100 \mu \mathrm{L}$ of $1 \times$ binding buffer containing $2 \mu \mathrm{L}$ of Annexin V-FLUOS and $2 \mu \mathrm{L}$ of PI and incubated for $15 \mathrm{~min}$ in the dark at room temperature, according to the manufacturer's recommendations (Roche, Germany). The results were then analyzed using flow cytometry. The analysis of the cell was executed by flow cytometry (FACScan; BD Biosciences) equipped with a Cell Quest software (BD Biosciences). Cells were divided to four quadrants namely living, early apoptotic, late apoptotic and necrotic cell.

\section{Data analysis}

Data were analyzed by using Microsoft Excel 2007 to obtain graph and linear regression for counting viability cell percentage and $\mathrm{IC}_{50}$ value The extract with smallest $\mathrm{IC}_{50}$ indicates the highest cytotoxic activity.

\section{RESULT AND DISCUSSION}

The results of cytotoxic activity of $P$. cauliflora stem fractions on T47D cancer cell lines are presented in 


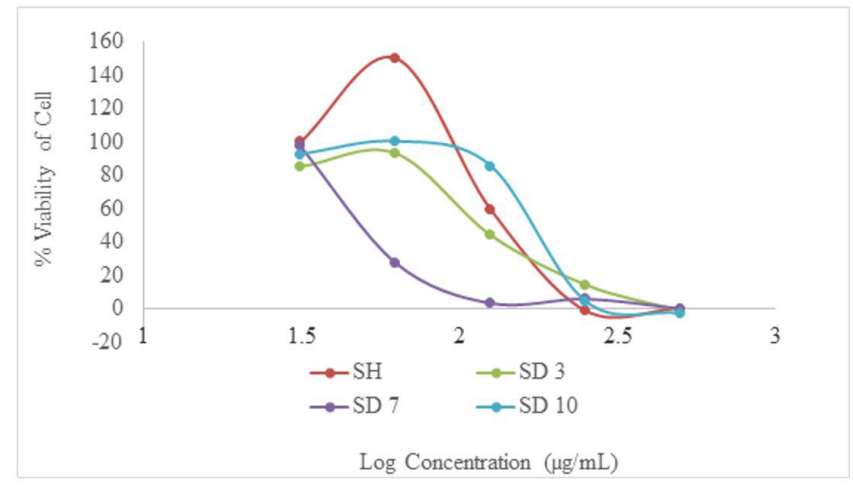

Figure 1. Cytotoxic activity of $P$. cauliflora stem fractions on T47D cancer cells

Figure 1. The observation was done on cancer cells treated with $P$. cauliflora stem fractions. It can be seen that the decrease of cancer cell viability is related to the fraction concentration. Dichloromethane fraction at $\mathrm{pH} 7$ demonstrated the highest inhibition to T47D proliferation. At concentration of $62.5 \mu \mathrm{g} / \mathrm{mL}$, the percentage of cancer cell viability declined to $27.54 \%$. Whereas, with the same concentration, the percentage of cancer cell viability for dichloromethane fraction at $\mathrm{pH}$ 3 was $93.33 \%$, dichloromethane fraction at $\mathrm{pH} 10$ was $79.30 \%$ and $n$-hexane fraction was $98.17 \%$. For some different fractions, dichloromethane fraction at $\mathrm{pH} 7$ (SD7) showed the highest cytotoxicity, with $\mathrm{IC}_{50}$ value of $59.29 \mu \mathrm{g} / \mathrm{mL}$. On another hand, the dichloromethane fraction at $\mathrm{pH} 10$ (SD10) had the lowest cytotoxicity, with an $\mathrm{IC}_{50}$ value of $130.32 \mu \mathrm{g} / \mathrm{mL}$ (Table 1). According to the fractions of cytotoxicity levels, the order of cytotoxicity was $\mathrm{SD} 7>\mathrm{SD} 3>\mathrm{SH}>\mathrm{SD}$.

The cytotoxic effects of plant extracts are usually caused by secondary metabolites in them. We assumed that alkaloids were compounds that were responsible for cytotoxic activity of $P$. cauliflora stem. Bisbenzylisoquinoline alkaloid has been reported to have various interesting biological activities including cytotoxic activities (Atta-ur-Rahman, et al., 2004; Wang et al., 2010; Lv et al., 2013), anticholinesterase (Cometa et al., 2012) and antimicrobial activities (LohomboEkomba et al., 2004). The potent cytotoxic activity of dichloromethane fraction at $\mathrm{pH} 7$ might be related to the high concentration of bisbenzylisoquinoline. Studies of the species of genus Pycnarrhena has been reported the presence of secondary metabolite compounds especially bisbenzylisoquinoline alkaloids (Sioumis and Vashist, 1972; Loder and Nearn, 1972; Siwon et al. 1981; van Beek et al., 1982; Abouchacra et al., 1987). Bisbenzylisoquinoline alkaloids from $P$. ozantha have been showed antitumor activity (Loder and Nearn, 1972). Masriani (2014) isolated bisbenzylisoquinoline alkaloid from $P$. cauliflora root. The compound also demonstrated potent toxicity activity against cancer cells Hela, MCF-7, T47D, WiDr and Raji with $\mathrm{IC}_{50}<4 \mu \mathrm{g} /$ $\mathrm{mL}$.

One of important properties possessed by anticancer drug candidate is an ability to induce apoptosis (Frankfurt and Krishan, 2003). To confirm whether the cytotoxic activity observed was due to apoptosis, the cell was stained by Annexin-V FLUOS/PI. Necrosis and apoptosis are two well-described pathways. As the most active substance, the dichloromethane fraction at pH 7 was selected for analysis of apoptosis on breast cancer cells T47D. The results of flow cytometer analysis (Table 2 and Figure 2) show a decline on the percentage of live cells with increasing concentrations of the fraction that is $89.21 \%$ in the control to $49.20 \%$, $44.02 \%$ and $34.46 \%$ after dichloromethane fraction administration in consecutive concentrations of 60,120 and $180 \mu \mathrm{g} / \mathrm{mL}$. Dichloromethane fraction at $\mathrm{pH} 7 \mathrm{might}$ induce apoptosis of cancer cells T47D which depends on the concentration characterized by increased percentage of early apoptosis of $4.32 \%$ in the control becomes $22.55 \%, 32.04 \%$, and $40.29 \%$ after administration of dichloromethane fraction in consecutive concentrations of 60,120 , and $180 \mathrm{mg} / \mathrm{mL}$. Although the increase of final apoptosis does not always in line with increasing

Table 1. Cytotoxic activities (MTT assay) of $P$. cauliflora stem fractions on T47D cancer cells

\begin{tabular}{ll}
\hline Fractions & $\mathbf{I C}_{\mathbf{5 0}}(\boldsymbol{\mu \mathbf { g }} / \mathbf{m L})$ \\
\hline$n$-hexane $(\mathrm{SH})$ & 125.60 \\
Dichloromethane fraction at $\mathrm{pH} 3(\mathrm{SD} 3)$ & 115.61 \\
Dichloromethane fraction at $\mathrm{pH} 7(\mathrm{SD} 7)$ & 59.30 \\
Dichloromethane fraction at $\mathrm{pH} 9$ (SD9) & 130.32 \\
\hline
\end{tabular}




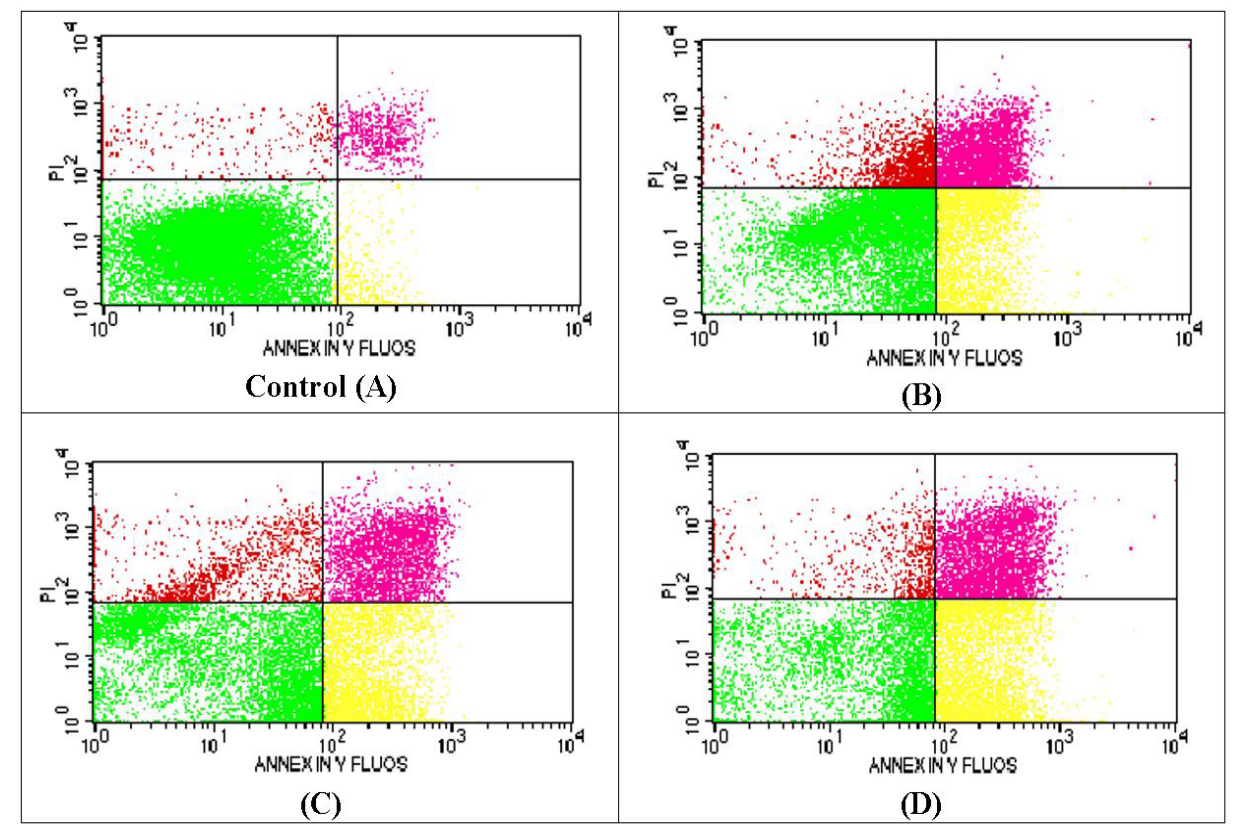

Figure 2. The induction of apoptosis on T47D cells by SD7. T47D cells were treated with various concentration of SD7 for $24 \mathrm{~h}$. The cells in solvent control group were treated with complete medium. The percentage of apoptotic cell was determined by annexin V-FLUOS/PI staining and examined by flow cytometry. The Annexin V-FLUOS-/ PI- (LL) was regarded as living cells, whereas annexin V-FLUOS+/PI-(LR) cells were taken as a measure of early apoptosis, annexin V-FLUOS+/PI+ (UR) as late apoptosis and annexin V-FLUOS-/PI+ (UL) as necrosis. Typical distributions of cell populations under the treatment of $0 / 60 / 120 / 180 \mu \mathrm{g} / \mathrm{mL}$ of SD7 were shown in (A)-(D), respectively

Table 2. Apoptosis induction of dichloromethane fraction at pH 7 of $P$. cauliflora stem on T47D cancer cells

\begin{tabular}{lllll}
\hline \multirow{2}{*}{ Cell condition } & \multicolumn{4}{c}{ Percentage of cell $(\mathbf{\%}) *$} \\
\cline { 2 - 5 } & Cell control & $\mathbf{6 0} \boldsymbol{\mu g} / \mathbf{m L}$ & $\mathbf{1 2 0} \boldsymbol{\mu g} / \mathbf{m L}$ & $\mathbf{1 8 0} \boldsymbol{\mu g} / \mathbf{m L}$ \\
\hline Living cell & 89.21 & 49.2 & 44.02 & 34.46 \\
Early apoptosis & 4.32 & 22.55 & 32.04 & 40.29 \\
Late apoptosis & 3.45 & 18.81 & 17.08 & 21.74 \\
Necrosis & 3.10 & 9.90 & 7.02 & 4.03 \\
\hline
\end{tabular}

*The percentage of cells in the Figure 2

dose, however the increase of total number of apoptosis was in line with increasing dose (Figure 3). The number of cells undergoing necrosis due to treatment of dichloromethane fraction at $\mathrm{pH} 7$ is not increased when compared to cells undergoing apoptosis. These data clearly suggest that SD7 induced apoptosis in T47D cell line.

\section{CONCLUSION}

Dichloromethane fraction at $\mathrm{pH} 7$ of $P$. cauliflora stem showed the highest cytotoxic activity on human breast cancer cell line T47D through induction of apoptosis. The result indicated the potential of dichloromethane fraction of P.cauliflora stem as a source of bioactive compounds and provided a basis of further studies to isolate a new anticancer compounds.

\section{ACKNOWLEDGEMENTS}

We are greatly thankful to the Ministry of Research, Technology and Higher Education, Republic of Indonesia, for supporting this investigation by grants "Fundamental Research' (036/SP2H/LT/DRPM/II/2016).

\section{REFERENCES}

Abouchacra, M.L. (1987). The bisbenzylisoquinoline alkaloid of Pycnarrhena ozantha. Journal of Natural Product, 50, 375-80. 


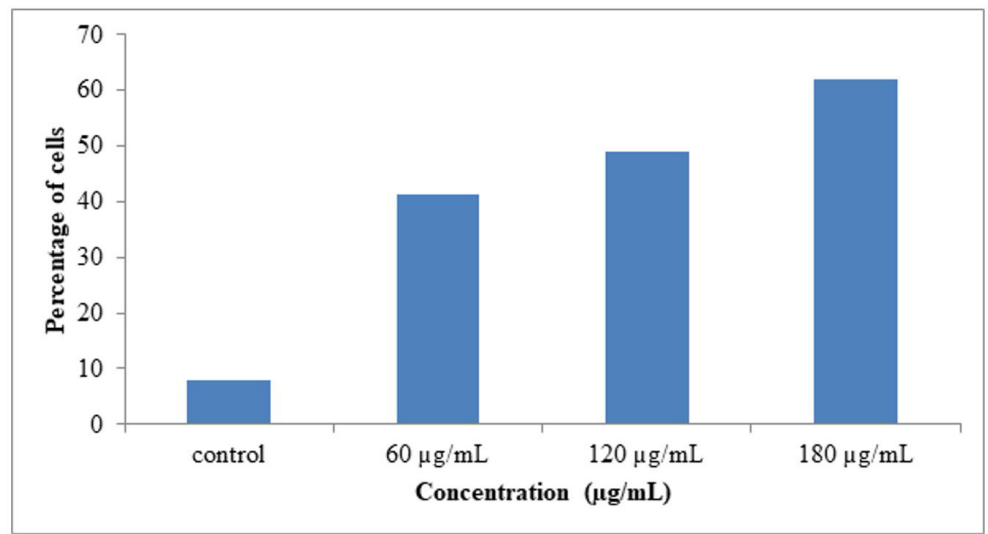

Figure 3. The total number of apoptosis of human breast cancer cells T47D after administration of dichloromethane fraction at $\mathrm{pH} 7$ of P.cauliflora stem

Afrianti, U.T. (2007). Kajian etnobotani dan aspek konservasi sengkubak [Pycnarrhena cauliflora (Miers) Diels] di Kabupaten Sintang Kalimantan Barat. [Thesis]. Postgraduate School. Bogor Agricultural University, Bogor (IN).

Alves, R.R. \& Rosa, I.L. (2005). Why study the use of animal products in traditional medicines? Journal of Ethnobiology and Ethnomedicine, 1(1), 5.

Atta-ur-Rahman, Wahab, A.T., Nawaz, S.A. \& Choudhary, M.I. (2004). New cholinesterase inhibiting bisbenzylisoquinoline alkaloid from Cocculus pendulus. Chemical and Pharmaceutical Bulletin, 52(7), 802-6.

Bray, F., Ferlay, J., Soerjomataram, I., Siegel, R.L., Torre, L.A. \& Jemal, A. (2018). Global cancer statistics 2018: GLOBOCAN estimates of incidence and mortality worldwide for 36 cancers in 185 countries. CA Cancer Journal for Clinicians, 68(6), 394-424.

Cometa, M.F., Fortuna, S., Palazzino, G., Volpe, M.T., Salgado, E.R., Nicoletti. M. \& Tomassini, L. (2012). New cholinesterase inhibiting bisbenzylisoquinoline alkaloids from Abuta grandifolia. Fitoterapia, 83, 47680 .

Frankfurt, O.S. \& Krishan, A. (2003). Apoptosis enzymelinked immunosorbent assay distinguishes anticancer drugs from toxic chemicals and predicts drug synergism. Chemico Biological Interactions, 145(1), 89-99.

Siegel, R.L., Miller, K.D. \& Jemal, A. (2018). Cancer Statistics, 2018. CA Cancer Journal for Clinicians, 68:7-30.

Li, R., Helman, R., Sachs, R. \& Duesberg, P. (2005). Chromosomal alterations cause the high rates and wide ranges of drug resistance in cancer cells. Cancer Gen. Cyt, 163, 44-56.

Loder, J. \& Nearn, R. (1972). Tumour inhibitory plants: Two new bisbenzylisoquinoline alkaloid from Pycnarrhena ozantha (Menispermaceae). Chemistry, 25(10), 2193-97.

Lohombo-Ekomba, M.L., Okusa, P.N, Penge, O., Kabongo, C., Choudhary, M.I. \& Kasende, O.E. (2004). Antibacterial, antifungal, antiplasmodial, and cytotoxic activities of Albertisia villosa. Journal of Ethnopharmacology., 93, 331-3.

Lv, J-J., Xu, M., Wang, D., Zhu, H-T., Yang,C-R., Wang, Y-F, Li, Y. \& Zhang, Y-J. (2013). Cytotoxic Bisbenzylisoquinoline Alkaloids from Stephania epigaea. Journal of Natural Product, 76, 926-32.

Masriani, Enawaty, E. \& Adnyana, I.K. (2011). Aktivitas antioksidan ekstrak etanol daun sengkubak (Pycnarrhena cauliflora (Miers) Diels) Asal Kalimantan Barat. Prosiding Seminar Nasional Herbs for Cancer, Universitas Islam Sultan Agung, Semarang (IN) 4 Juni 2011.

Masriani, Mustofa, Jumina \& Sunarti (2013). Pycnarrhena cauliflora Ethanolic Extract Induces Apoptosis and Cell Cycle Arrest in Hela Human Cervical Cancer Cells. International Journal of Research in Pharmaceutical and Biomedical Sciences, 4(4), 1060-9.

Masriani, Mustofa, Jumina, Sunarti \& Enawaty, E. (2014). Cytotoxic and induction apoptotic activity of crude alkaloid of Pycnarrhena cauliflora Root in Human Breast Cancer T47D Cell Line. Scholars Academic Journal of Biosciences, 2(5), 336-40. 
Masriani (2014). Potensi Antioksidan dan Antikanker Alkaloid Bisbenzilisokuinolin dari Akar Sengkubak [(Pycnarrhena cauliflora (Miers) Diels]: Isolasi, Sitotoksisitas, dan Mekanisme Aksinya. [Disertasi]. Doctoral Program. Gadjah Mada University, Yogyakarta, [IN].

Newman, D.J. \& Cragg, G.M. (2007). Natural products as sources of new drugs over the last 25 years. Journal of Natural Product, 70(3), 461-77.

Mosmann T. (1983). Rapid colorimetric assay for cellular growth and survival: application to proliferation and cytotoxicity assays. Journal of Immunological Methods, 65(1-2), 55-63

Rogers, L.R. (2003). Cerebrovascular complications in cancer patients. Neurologic Clinic, 21, 167-92.

Sausville, E.A. \& Longo, D.L. (2005). Principle of cancer treatment: Surgery, chemotherapy, and biologic therapy in: Harriot's Principles of Internal Medicine, Vol. I, McGraw-Hill, New York, 466-477.

Sioumis, A.A. \& Vashist, V.N. (1972). New bisbenzylisoquinoline alkaloid from Pycnarrhena australiana (Menispermaceae). Australian Journal of Chemistry, 25, 2251-4.
Siwon, J., Verpoorte, R., van Beek, T., Meerburg, H. \& Svendsen, A.B. (1980). Alkaloids from Pycnarrhena longifolia. Phytochemistry, 20, 323-25.

Taraphdar, A.K., Roy, M. \& Bhattacharya, R.K. (2001). Natural products as inducer of apoptosis: implication for cancer therapy and prevention. Curr. Sci., 80(11):138796.

Tsuruo, T. (2003). Molecular cancer therapeutics: recent progress and targets in drug resistance. Internal Medicine, 42(3), 237-43.

Wang, J.Z., Liu, X.Y. \& Wang, F.P. (2010). Two new curine-type bisbenzylisoquinoline alkaloids from the roots of Cyclea wattii with cytotoxic activities. Chemical and Pharmaceutical Bulletin, 58(7), 986-8.

Van Beek, T., Veerporte, R. \& Svendsen, A.B. (1982). Colorflammine and berbacolorflammine, two new orange-colored bis[benzylisoquinoline] alkaloids from Pycnarrhena longifolia. J.Org. Chem, 47:898-900.

Vijayalaxmi, B., Thomas, C.R., Reiter, R.J. \& Herman, T.S. (2002). Melatonin: from basic research to cancer treatment clinics. Journal Clinical Oncology, 20, 2575601. 